\title{
Holden Caulfield: A Marginal Player Made by Historical Context
}

\author{
Zari Dorri \\ Department of English Literature, Faculty of Humanities, Kharazmi University,Tehran, Iran \\ E-mail: z.dorri66@yahoo.com
}

Keywords: Holden Caulfield, The Catcher in The Rye, Phoniness, Social Factors, Ambience

\begin{abstract}
Holden Caulfield, the major character in Jerome David Salinger's most rewarded novel The Catcher in the Rye, long stood as the innovative and leading figure for such distinctive and revolutionary traits in a character he presented in 1959s' America literary domain. Salinger mediashy and no interview policies led the public to spread out the idea of the author's being the whole genius behind the sheer novelty of Holden Caulfield character by making a myth out of the author who turns down any kind of publicity and is finally lionized. This student-friendly hero who denigrate respectability and" phoniness" with his cynical attitude and obscene language, in one way or another, is kept being compared to such huge characters like Huckle Berry Finn whose universal popularity is barely deniable; but the question is that, could at any rate, J.D. Salinger be the sole innovator behind this genuineness? On the other hand, are there any other social and environmental factors, which came to pave the way for any kinds of Holden to be born and well liked? The main purpose of the paper is to answer these questions by a kind of critical theory as New Historicism and survey through the history as a discourse in this method. The results and findings indicate that, apparently, there was a specific social context for the emergence of this novel, with which the author had to interact. By opening up the environmental condition of those days and considering the facts, which affected Holden's birth and popularity in that era. This essay will point out the fact that criticizing America's 50s in such aforementioned ambience was inevitably and to some extent predictable.
\end{abstract}

\section{Introduction}

Jerome David Salinger's Holden Caulfield has almost unfailingly been treated as the author's brainchild suddenly springing out of his imagination. Additionally Salinger's media-shy, recluse personality and his no-interview policy spanning decades following his novel's publication have legitimately contributed to the myth that The Catcher in the Rye's popularity came directly from Salinger's genius and independent portrayal of Holden Caulfield, the college student-friendly hero who expresses contempt for respectability and "phoniness". In 1958 critics Frederick L. Gwynn and Joseph L. Blotner noted in their study of J.D. Salinger that 'it is not inconceivable that someday Holden Caulfield may be as well known an American boy as Huck Finn' [1]. The success of the novel that followed not only proved their argument coming to life but also affirmed Holden's popularity with his cynical attitude and obscene language even more than his predecessor affirm. In the light of the present and past success of the novel, the argument of this essay is that it is legitimately justified to discard the notion that Salinger is the sole genius behind the Holden Caulfield puppet. We will do so by opening to the reader the context with which this novel and its author inevitably had to interact. The bulk of the available evidence in the course of this essay points to the fact that, to put it in socio-political terms, Salinger's novel criticizing the American status quo of nineteen fifties is not a phenomenon anomalous, independently deviating from the norm. Rather the novel has its piercing voice and intensifying role in the unorganized but vociferous ensemble of defiance and disapproval of fifties. Furthermore, throughout the essay the reasons why The Catcher in the Rye was one of the major works, which received such diverse criticism amid the wide range of works with more or less the same theme, is put forward to the reader.

Among too many articles and books about the reasons of popularity and uniqueness of the catcher, one could see the subjects such as alienation, innocence of childhood, the adolescent crisis, and the psychological personality of Holden and other characters, etc. Every reader and critic very 
often relate its popularity to a particular reason, as we relate it to the unique situation and ambience of the era, not just to the genuineness of the creator.

In a similar attempt, rejecting the work being the product of mere imagination of the author, Gish Jen (2010) suggests that the work is substantially a kind of autobiography, based on Salinger's statements. In a 1940 letter to a friend, a 21-year-old Salinger described his novel-in-progress as "autobiographical"; and decades later, too, in an interview with a high school reporter - the only interview he's ever given - Salinger said, "My boyhood was very much the same as that of the boy in the book." Of course, there were differences: unlike Holden, Salinger was, among other things, a half-Jewish, half-Catholic brotherless World War II vet who attended a military academy. He did, though, like Holden, flunk out of prep school. And he was, like Holden, manager of his high school fencing team, in which capacity he apparently really did once lose the team gear en route to a meet. More importantly, Salinger seems to have shared Holden's disaffection. Numerous youthful acquaintances remember him as sardonic, rant-prone, a loner. His daughter, Margaret Salinger, likewise traces the alienation in the book to him, though it does not reflect for her either her father's innate temperament or difficult adolescence so much as his experiences of anti-Semitism and, as an adult, war. Where Salinger fought in some of the bloodiest and most senseless campaigns of World War II and apparently suffered a nervous breakdown toward its end, shortly after which while still in Europe - he is known to have been working on Catcher - it is hardly surprising that Holden's reactions should evoke not only adolescent turmoil but also the awful seesaw of a vet's return to civilian life. Holden may be a rebel without a cause, but he is not a rebel without an explanation: It is easy to read the death of his brother as a stand-in for unspeakable trauma. And witness the notable vehemence with which Holden talks about the war - declaring, for instance, "I'm sort of glad they've got the atomic bomb invented. If there's ever another war, I'm going to sit right the hell on top of it. I'll volunteer for it, I swear to God I will."[2]

Neffinger (2014) in his thesis as "Hippie Caulfield: The Catcher in the Rye's Influence on 1960s American Counterculture" again relates its popularity to Holden`s peculiar personality and historical context and writes Catcher's popularity during the countercultural era of the 1960s was largely due to Holden's introspective honesty about himself and others around him. Following an era of intense nationalism during the $1950 \mathrm{~s}$, countercultural youth gravitated towards Holden as a representative voice for their dissatisfaction with the "American Way" of their parents. [3] He concludes that Holden's postmodern influence on the counterculture exists in the very fact that he became a literary figure for countercultural youth. Rather than accepting an identity in their parents or their culture, many countercultural youth looked to Holden as an embodiment of their identity. The novel's popularity, especially among youth, following the 1960s speaks not only for the novel's literary qualities but also for its ability to connect with youth culture during and after the countercultural era.

On the other hand, Manyard (2002) in his review of a book by Pamela Hunt Steinle as "In Cold Fear: The Catcher in the Rye Censorship Controversies and Postwar American Character" analyzes and summarizes the reasons of the novel unpopularity and its flaws in authorities' viewpoints in 1950s and 1960s. He states that the writer, P.H. Steinle, believes that more than fifty years after its publication, Catcher is still the most assigned and most censored book in America. She interviewed the major participants in the attempt of censors and they said that catcher presented a "negative" view of the world that they did not want their children to adopt. The issue was not the right of free expression but the power to assign. The disagreement was over "what 'truth' ought to be shared with adolescents". The fear was that Holden Caulfield would persuade people as young as he to have no values at all-and that America was already well advanced in that direction. Manyard concludes that as a study of the role of postwar censor- ship, In Cold Fear contains a major omission. In the 1950s and 1960s, while private citizens were trying to keep Catcher off the high school library shelves, government censors were still trying to keep other books from being read at all, usually by making it a crime to send them through the mail. And in one high-profile case after another, the official censors lost and lost miserably. This is the legal backdrop for the persecution of Catcher. Yet it is missing from this book. The author takes no note 
of such actions as the trial over Allen Ginsberg's Howl (1956) in San Francisco, the trial about William Burrough's Naked Lunch (1959) in Boston, or the lifting of the post office bans on D.H. Lawrence's Lady Chatterley's Lover (1928), John Cleland's Fanny Hill (1749), and all of Henry Miller's novels. Even if Catcher was spared this kind of frontal assault, the surprising weakness and long, humiliating retreat of official censorship certainly had an effect on the way private individuals and organizations tried to carry on the fight. It may even have convinced them to fight harder. [4]

As a conclusion, it should be noted that neither this article nor any other one directly rejects the ingenuity of Salinger, but I tried to collect and focus on almost all aspects of the historical and social characteristics which caused to creating this genius and this peculiar character.

\section{Methodology}

During the history of literary criticism, the challenges on considering historical and social setting and context always have been a place of discussion. After the first half of $20^{\text {th }}$ century and disavowing the principles of New Criticism movement, by its focusing on the text itself rather than on historical, authorial, or reader concern, almost all critics in different modern literary movements and strategies agreed on the impossibility of ignoring the milieu of both the author and the reader.

Appearing in 1970s and the early 1980s, New Historicism declares that history is one of many courses, or ways of seeing and thinking about the world. By highlighting and viewing history as one of many equally important discourses such as sociology and politics and by closely examining how all discourses (including that of textual analysis) affects a text interpretation, New Historicism claims that it provides its adherents with a practice of literary analysis. [5]

In studying my paper I followed the methodology and assumption of this literary movement and concluded that this novel, like all other works of art, shaped by social forces in its time and history is not just a background for textual analysis, but is an essential element in the interpretive process.

\section{Discussion}

Literary works, no matter how original and inventive or conventional and clichéd, are not created in the sterile, virgin soil of their creators' minds. An author is, consciously or unconsciously, either reacting against or cooperating with the environment he happens to interact with (be it social, political, psychological, or historical). Even Salinger who had given no official interviews since the mid-1950s, had not published even a single line since 1965, fiercely resisting any other kind of reprinting or commercial exploitation of his work, in one way or another had been influenced and affected by the sweeping wave of changes, oppositions and frictions that America of fifties ineluctably had to undergo. The intended scope of the aforementioned argument will be the trouble spots of cultural, artistic, historical, and political spheres of America during fifties. [6]

Published in 1951, years following the Second World War, Catcher in the Rye found its readers in what the American poet Robert Lowell called "the tranquilized fifties": "These are the tranquilized Fifties, / and I am forty. Ought I to regret my seedtime?" [7]. The readers of Catcher in the Rye lived through fifties with Dwight Eisenhower presiding over the U.S., who enjoyed tremendous approval ratings through fifties. He was a war hero whose first objective was to instill confidence and assurance in U.S. citizens [8].It is not an empty guess then to say that the order of the day was stability; business was booming. When the economic boom of post-war America is mentioned, what is indicated is the increasing prosperity of the white population, not of all Americans. Catcher makes clear that Holden lives a very comfortable life in material terms and so there is little sense in the novel that life is changing rapidly for the average American. After the deprivations of the Depression and the war, America was becoming comfortable and materialistic, at least for those in the white educated middle class. In a deeper political level, opportunistic politicians like Joseph McCarthy pressured and even prosecuted the radicals. The Wisconsin Senator aimed to smoke out all communists. Sarah Graham believes that, "Carl Luce, Holden's 
student adviser from his previous school, is an interesting character to be considered in the context of the McCarthy era. Many of McCarthy's targets were homosexual men: McCarthy's prosecution of them under the guise of anti-Communism concealed homophobia in an era when homosexuality was illegal and socially unacceptable to many people" [9]. Holden tells us that "Old Luce knew who every flit and Lesbian in the United States was. All you had to do was mention somebody anybody - and old Luce'd tell you if he was a flit or not' [10]. Luce seems to be a McCarthyesque figure, the holder of secret shameful information; he is also, like some of McCarthy's victims, able and willing to 'name names'. Thus, Holden's confusion and anxieties about sex are very typical of the era in which he lives; many people lived in a state of ignorance about sexual matters and seemingly, their upset conscience was obsessed and racked with guilt at the sexual ambience trying to permeate the society.

Women who had greatly contributed to society and gained some stature in working places during the war years were sent to their kitchen exiles, because the veterans of the war were back in. This led to revived gender discrimination. This increased the population of childbearing women which led to 'Baby Boom' of the 1950s, which would lead to an unusually large group of adolescents and students in the late 1950s and 1960s, many of whom demanded new ways of living that challenged the values of their parents, producing the so called 'generation gap'. The theme of the difficulty with adolescence invoked an affluent attention from the new generation. Growing up is often intolerable in a society that does not provide stability and values to the youth on the verge of adulthood. Holden recognizes the conventions that govern his society and usually conforms to them, but at the same time, his disillusionment with the adult world anticipates the adolescent rebellions of a later period. In this strained atmosphere, signs of turmoil and dissent began to surface.

The "Baby Boom" caused Americans to pay more attention to the younger generation. While Catcher in the Rye was somewhat ahead of its time in this regard, the subject had particular relevance in the years after its publication. Lifestyles began to change dramatically as teenagers began to date and become sexually active at a younger age. Teenagers became more rebellious, a trend that their parents viewed to be strongly influenced by a new form of music called rock ' $n$ ' roll.

All the cultural scenes of the 50s typified this new attitude of rebelliousness. Juvenile delinquency became an alarming problem and it was considered as a major social issue. Teens were skipping classes and committing crimes, and parents were alarmed by their children's lack of respect for authority. In Hollywood, actors such as James Dean and Marlon Brando starred in movies representing unsentimental navigations of life's nasty faces such as On the Waterfront. James Dean portrayed a popular image of a young person in Rebel without a Cause (1955); this time not a conforming one but a resisting youth who relentlessly challenges the authority with what it seems groundless reasons. A play by Tennessee Williams called A Streetcar Named Desire unloosed a tide of sexuality and violence across the U.S. The purchase of rock 'n' roll records by kids in the 1950s proved a relatively safe and affordable way for kids to assert generational identity through rebellion against previous adult standards and restrictions of musical style and taste. [11]Elvis Presley was the musical star of the era whose twirling hips stroke the sexual provocation strings of his fans threatened the moral conformity of the youth of fifties. [11]It would not be an exaggeration to say that the 1950s essentially invented the teenager as a commercial and cultural entity, and that rock 'n' roll music, along with television and, to some extent, movies, played an essential role in this invention.[11]

America's literature of fifties witnessed Allen Ginsberg's Howl and Jack Kerouac's On the Road, both iconic announcements of cultural dissent and disapproval, both rejecting the social values of their time. The novels of this period reflected a growing sense of despair, paranoia, and irrational violence. It was in this social climate and amongst the company of such noted authors as Saul Bellow, Norman Mailer, Kurt Vonnegut, and Thomas Pynchon, that J.D. Salinger emerged.

Holden Caulfield sprouted out amid this controversial setting, yet struck a more powerful chord with the disenchanted youth of 1950s. Many readers, young and old, identified with Holden 
Caulfield's rebellion against the world of "phoniness" and the rejection of adult values and morals in American society.

Alfred Kazin comments scathingly that Salinger has acquired a vast readership by flattering those who 'think of themselves as endlessly sensitive, spiritually alone, gifted, and whose suffering lies in the narrowing of their consciousness to themselves, in the withdrawal of their curiosity from a society which they think they understand too well' [12]. Moreover, because Salinger's readers tend to be young people, this may even be irresponsible.

Beth Bailey says in her essay "Sexuality and the Movements for Sexual Liberation" in that time "American society was moving toward changes in sexual behaviors and sexual mores. The role of sex in the popular culture, the increased acceptance of gender equality and reproductive freedoms, and the growing visibility of gay men and lesbians in American society,"'[8], were dealing with sexual tendencies from a young teenager's point of view who is entering the complex world of adulthood. As William Wiegand puts it correctly, "it offers the readers a new, provocative kind of fiction that responds to contemporary concerns," [13]. Therefore, Salinger's work 'answers a need for a different kind of treatment of experience'. Holden is the manifestation of the American Adam who fitted perfectly in the time when there was a "steep rise in the prescribing of tranquillizers", the time that is "indicative of a culture that treated unhappiness as an illness rather than the product of oppressive social standards" [9]. Like most teenagers, Holden struggles with his sexuality. He considers himself a "sex maniac," but he is also completely inexperienced. In addition, he has very strong and often contradictory feelings about women. Most women, such as Bernice Krebs and Sally Hayes, he sees as utterly stupid, largely because they seem interested in boys and men whom, Holden knows from experience, are up to no good. On the other hand, Holden sees Jane Gallagher as a perfect woman: kind, loving, gentle, innocent, and wonderful. In other words, he idealizes her. Yet the fact that he is so frightened to call or talk to her implies that he knows that she cannot possibly be as perfect as he wants her to be. In the end, Holden's feelings about women and sex mirror his feelings about society as a whole.

Salinger's Holden Caulfield both reflected and helped to commence a countercultural mobilization with all-embracing and sweeping consequences. Salinger's novel must have had ridden successfully on this wave of contrast and confrontation which erupted in America of fifties. The Catcher in the Rye is a book with its colloquial and rough language and its embodiment of the issues of a capitalist country facing economical, sexual and political repressions and limitations. In addition, it is a book with a universal theme with a great timing, using the social, political and even issues, which were considered as taboos before, appealed to a young generation who could identify with Holden, a young boy dealing with the same problems as themselves.

\section{Conclusion}

If The Catcher in the Rye were introduced as a new book today, it would certainly not be considered as shocking now as it was in the 1950s. Catcher in the Rye is still read today by the masses because they live and breathe in the same ambience of questioning the authority and challenging the dominant values. In this context, few fictional characters mirroring these sociopolitical developments embedded themselves on the public consciousness more indelibly than Holden, the Catcher in the Rye.

To accord with such an environment, socially and politically, regarding the all-inclusive aspects of all the distinctive spheres, the artistic products could not get away with the changes of the era. Holden Caulfield, a product belonging to this very environment of sweeping reforms, could not ever be perceived and believed to be the mere creation of its originator, J.D. Salinger. Along with all the artistic and specifically literary contributions to the modern transforming America, Holden Caulfield came to be one of the most boisterous and as well equally important influential products of the day. 


\section{References}

[1] F.L. Gwynn, J.L. Blotner, The Fiction of J.D. Salinger, University of Pittsburgh Press, Pittsburgh, 1958.

[2] G. Jen, Why do people love 'Catcher in the Rye'. Available: https://newrepublic.com/article/72860/why-do-people-love-catcher-the-rye.

[3] R.V. Neffinger, Hippie Caulfield: The Catcher in the Rye's influence on 1960s American counterculture, M.A. thesis, Dept. General Studies, Liberty Univ., Virginia, 2014.

[4] J.A. Manyard, Review: In Cold Fear: The Catcher in the Rye Censorship Controversies and Postwar American Character, The Journal of American History. 89(2) (2002) 714-715.

[5] E.B. Charles, Literary Criticism, an introduction to theory and practice, Pearson Education Ltd., London, 2007.

[6] J. Moran, Star Authors: Literary Celebrity in America, Pluto Press, London, 2000.

[7] R. Lowell, Life Studies, Farrar, New York, 1959.

[8] B. Bailey, Sexuality and the movements for sexual liberation, in: Jean-Ch. Agnew, R. Rosenzweig, A Companion to Post-1945, Blackwell Publications, Oxford, 2002, ch. 14, pp. 260, ch. 19, pp. 375.

[9] S. Graham, J.D Salinger's The Catcher in the Rye: A Routledge Study Guide, Routledge, London, 2007.

[10] J.D. Salinger, The Catcher in the Rye, Penguin, London, 1994.

[11] L. Starr, C. Waterman, American popular music: The rock Years, Oxford University Press, Oxford, 2005, pp.54-57.

[12] A. Kazin, J.D. Salinger: 'Everybody’s Favorite', Atlantic Monthly. 208(2) (1961) 67-75.

[13] W. Wiegand, The Knighthood of J.D. Salinger. Available: https://newrepublic.com/article/72842/the-knighthood-jd-salinger. 